\title{
Lineage Development in a Patient without Goblet, Paneth, and Enteroendocrine Cells: A Clue for Intestinal Epithelial Differentiation
}

\author{
RON SHAOUL, DON HONG, YOSHIO OKADA, ERNEST CUTZ, AND MARGARET A. MARCON \\ Department of Pediatrics [R.S.], Bnai Zion Medical Center, Faculty of Medicine, Technion-Israel Institute \\ of Technology, Haifa 31048, Israel; Division of Gastroenterology and Nutrition [R.S., D.H., M.A.M.], \\ Hospital for Sick Children, Departments of Pediatrics and Pathology [E.C.], University of Toronto, \\ Toronto, Ontario M5G 1X8, Canada; and Department of Nutritional Science [Y.O.], Faculty of Health \\ and Welfare Science Okayama Prefectural University, Soja, Okayama 719-1197, Japan
}

\section{ABSTRACT}

We report a patient who presented with severe enterocolitis and apparent absence of Paneth, goblet, and enteroendocrine lineages from the small bowel and colon. The absorptive enterocyte seemed to be normal morphologically and functionally. Because normal enterocytes were present, we hypothesized that this patient had a developmental block in the differentiation of a common stem cell precursor for Paneth, goblet, and neuroendocrine lineages. By using antibodies to protein markers of each cell line, including some that are expressed early in the differentiation process, we aimed to study lineage development in this patient. From our data, we surmise that there may be a two-step process in lineage commitment. The stem cell may commit to an absorptive cell or a granule-containing cell. The daughter cell that is committed to the granule lineage then further commits to a goblet, enteroendocrine, or Paneth cell lineage. (Pediatr Res 58: 492-498, 2005)

CMG, Chromogranin A

HD, human defensin

H\&E, hematoxylin and eosin

IBD, inflammatory bowel disease

MUC, mucin

PAS, periodic acid-Schiff

TFF, Trefoil factor family
The intestinal crypts contain a population of multipotential stem cells from which all of the epithelial cell lineages are derived. On the basis of work in mice, a common progenitor cell located near the base of the crypt of Lieberkühn is thought to give rise to all four intestinal cell lines: absorptive enterocytes as well as Paneth, goblet, and enteroendocrine cells (1-4). Much work has been done to understand the differentiation and development from stem cells to the various terminally differentiated cell types of the intestinal epithelium and the factors that play a part in this process. Many factors have been implicated in this process, such as Wnt/ $\beta$-catenin signaling (5); Notch signaling, including the transcription factors Math1 (6) and Hes1 (7); homeobox transcription factors Cdx1

Received November 17, 2004; accepted February 3, 2005.

Correspondence: Ron Shaoul, M.D., Pediatric Day Care Unit, Department of Pediatrics, Bnai Zion Medical Centre, 47 Golomb Street, Haifa 31048, Israel; e-mail: shaoul_r@012.net.il.

R.S. was a Canadian Cystic Fibrosis Foundation Research Fellow; he was also supported by grants from the American Physicians Fellowship for Medicine in Israel program, Janssen/Ortho Inc., and the Postgraduate Dyson Fellowship award from the University of Toronto. D.H. was a Canadian Cystic Fibrosis Foundation Research Fellow.

DOI: 10.1203/01.PDR.0000179408.74781.C9 and Cdx2 (8); Kruppel-like factors KLF4 and KLF5 (9-11); transcription factor Elf3 (12); platelet-derived growth factor (PDGF) A and its receptor, PDGF-Ra; the winged helix transcription factor Fkh6; the homeodomain transcription factor Nkx2-3; and Hox and ParaHox cluster genes, Sonic hedgehog, and bone morphogenetic proteins (13).

Intestinal differentiation is difficult to study because of the technical challenge of growing nonmalignant epithelial cells in vitro. Although much has been learned from the use of normal, chimeric, and transgenic mice models, the process is still very ill defined. The work of Cheng and Leblond (2) on mouse models introduced the idea that the stem cell is the direct progenitor of each of the terminal lineages.

We report a patient who presented with severe enterocolitis and apparent absence of Paneth, goblet, and enteroendocrine lineages from the small bowel and colon. The absorptive enterocyte seemed to be normal morphologically and functionally. Because normal enterocytes were present, we hypothesized that this patient had a developmental block in the differentiation of a common stem cell precursor for Paneth, goblet, and neuroendocrine lineages. These lineages have in common 
the packaging of proteins into secretory granules before regulated secretion. By using antibodies to protein markers of each cell line, including some that are expressed early in the differentiation process, we aimed to study lineage development in this patient. From our data, we surmise that there may be a two-step process in lineage commitment. The stem cell may commit to an absorptive cell or a granule-containing cell. The daughter cell that is committed to the granule lineage then further commits to a goblet, enteroendocrine, or Paneth cell lineage.

\section{CASE REPORT}

The patient presented at $14 \mathrm{y}$ of age with severe watery, predominately nonbloody diarrhea; some lower abdominal cramping; and an 11-kg weight loss over a 2- to 3-mo period. He had experienced mild intermittent diarrhea since the age of $2 \mathrm{y}$ and more persistent diarrhea over the last $2 \mathrm{y}$. Laboratory values at presentation are shown in Table 1 .

A double-contrast barium small bowel follow-through demonstrated nodularity and some polyposis of the jejunum and terminal ileum. A gallium scan was normal. A computed tomography scan of the abdomen demonstrated thickening of the colon, consistent with pancolitis, and small nodes in the mesentery, porta hepatis, and para-aortic areas.

Multiple cultures for enteric pathogens including Escherichia coli 0157:H7, Clostridium difficile, and parasites were negative. Tuberculin skin testing was negative, and a chest $\mathrm{x}$-ray was normal. Extensive immunologic testing was performed (Table 1). Results of immunohistologic studies are reported in Table 2.

Stomach. The stomach showed mild gastritis. Both staining and culture for Helicobacter pylori were negative. Antral sections stained with hematoxylin and eosin (H\&E) and periodic acid-Schiff (PAS)/Alcian Blue suggested that mucussecreting cells were present in normal amounts. Sections were also examined by immunohistochemistry to determine whether secretory products of neuroendocrine and mucus-secreting cells were normally expressed. Figure 1 compares the distribution of Chromogranin A (CMG), an early marker of neu-

Table 1. Laboratory values at the time of presentation

\begin{tabular}{lcc}
\hline \multicolumn{1}{c}{ Test } & Patient & Normal values \\
\hline Hemoglobin & $121 \mathrm{~g} / \mathrm{L}$ & $120-16 \mathrm{~g} / \mathrm{L}$ \\
MCV & 71 & $80-94 \mathrm{fL}$ \\
White cell count & 5.5 & $4.0-10.0 \cdot 10^{9} / \mathrm{L}$ \\
Platelet count & $276 \times 10^{9} / \mathrm{L}$ & $150-400 \times 10^{9} / \mathrm{L}$ \\
Serum Albumin & $28 \mathrm{~g} / \mathrm{L}$ & $33-58 \mathrm{~g} / \mathrm{L}$ \\
IgA, M, G, E and C3, C4 and CH50 & Normal & \\
Antibodies: ASMA, ANA, AMA, APCA & Negative & \\
ANCA and EMA, & Negative & \\
Anti-enterocyte Antibody & Negative & \\
Anti-goblet cell antibodies & Positive & \\
Serum gastrin & $<25 \mathrm{ng} / \mathrm{L}$ & $<90 \mathrm{ng} / \mathrm{L}$ \\
Urine VMA screen & Normal & \\
HIV serology & Negative & \\
\hline
\end{tabular}

Abbreviations: ANCA, antineutrophil cytoplasmatic antibody; ANA, anti nuclear antibody; AMA, anti mitochondrial antibody; ASMA, anti smooth muscle antibody; APCA, anti parietal cell antibody; EMA, endomesial antibody; MCV, mean cell volume; VMA, vanilmandelic acid. roendocrine cells, and MUC5AC (gastric mucin) in antral sections from the case with a histologically normal control biopsy specimen. CMG-containing cells were present in both biopsy specimens in the basal one third of the antral glands (Fig. $1 a$ and $b$ ). MUC5AC-containing cells (Fig. $1 c$ and $d$ ) occupied similar superficial areas of antral glands in biopsy sections from our case and normal control sections. Trefoil factor 1 (TFF1), part of the intestinal trefoil family, was normally expressed in superficial portions of antral glands from our patient (data not shown). There was also no evidence of either MUC2 or TFF3, products of small intestinal and colonic goblet cells, thus providing no evidence of aberrant expression of intestinal antigens.

Small intestine. The duodenum showed diffuse duodenitis. Duodenal biopsy sections are shown in Fig. 2. Sections from the patient that were stained with H\&E (Fig. 2a) showed a moderate increase in inflammatory cells within the lamina propria, some villus blunting, but no atrophy, with a slightly increased crypt:villus ratio. The outstanding feature, however, is the absence of goblet cells in both villi and crypts, similar to a case described by Moore et al. (14). This feature is even more striking in sections that were stained by PAS/Alcian Blue, which reveal an intact brush border without goblet cells (Fig. $2 b$ ), and is contrasted with sections similarly stained from a control biopsy that show multiple Alcian Blue-positive goblet cells in a similar area (Fig. 2c). The intact brush border on villus cells from the patient's duodenal biopsies was confirmed by electron microscopy. Figure $2 d$ shows that the brush border surface of villus enterocytes stained normally for sucrase, confirming the chemical evidence that biopsies contained normal quantities of brush border enzymes. In addition, enterocyte disaccharidase levels (trehalase, lactase, sucrase, maltase, and cellobiase) were normal.

In contrast to the apparent preservation of enterocytes, there was no evidence that duodenal biopsies from the case study expressed the mucus cell antigens MUC2, MUC5AC, TFF1, and TFF3; enteroendocrine products CMG, gastrin, and serotonin; or the early Paneth cell marker human defensin 5 (HD5). Figure $2 e$ depicts, as an example, a biopsy specimen from a control biopsy showing the localization of CMG within typical enteroendocrine cells in both crypts and villi, whereas a similar area from the patient shows no staining (Fig. 2f). Similarly, Fig. $2 g$ shows no staining for the MUC2 core antigen throughout the mucosa from the patient, whereas a control biopsy (Fig. $2 h$ ) reveals the normal distribution of this antibody within the endoplasmatic reticulum (ER)/Golgi zone of goblet cells.

The absence of Paneth, goblet, and enteroendocrine cells was confirmed by electron microscopy (data not shown). A few cells were noted that to contain dense granules that resembled neurosecretory granules, but $\mathrm{CMG}$ could not be detected within these granules using immunogold staining.

We further studied the small bowel proliferation using MIB1 (KI-67), a nuclear antigen that is associated with proliferation and found throughout the cell cycle and is absent in resting cells (15). The staining showed normal proliferation pattern (staining in crypts only) in the patient's duodenum compared with normal and Crohn's control subjects. 
Table 2. Results of immunostaining in the gastrointestinal tract

\begin{tabular}{|c|c|c|c|c|c|c|c|}
\hline & MUC2 & TFF3 & MUC5AC & TFF1 & HD5 & Sucrase & CMG \\
\hline \multicolumn{8}{|l|}{ Antrum } \\
\hline Control & Neg. & Neg. & Pos. & Pos. & Neg. & NA & Pos. \\
\hline Patient & Neg. & Neg. & Pos. & Pos. & Neg. & NA & Pos. \\
\hline \multicolumn{8}{|l|}{ Duodenum } \\
\hline Control & Pos. & Pos.(‡) & Neg. & Neg. & Pos. $(\ddagger)$ & Pos.(‡) & Pos. \\
\hline Crohn's & Pos. & 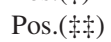 & Neg. & Pos. & Pos. $(\dagger)$ & Pos.(抹) & Pos. \\
\hline Patient & Neg. & Neg. & Neg. & Neg. & Neg. & 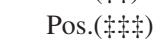 & Neg. \\
\hline \multicolumn{8}{|l|}{ Colon } \\
\hline Control & Pos. & Pos. & Neg. & Neg. & Neg. & NA & Pos. \\
\hline Patient & Pos. II & Pos.II & Pos. $\S$ & Pos.§ & Neg. & NA & Neg. \\
\hline
\end{tabular}

MUC2, The major intestinal mucin includes results of core and glycosylated MUC2; MUC5AC, The major gastric mucin; TFF3 (ITF), Trefoil factor 3, The intestinal trefoil factor; TFF1 (pS2), Trefoil factor 1, The gastric trefoil factor; HD5, Human defensin 5 (A Paneth cell marker); CMG, Chromogranin A (also serotonin and gastrin) Enteroendocrine markers.

$\ddagger$ Implicates stain intensity.

II Unlike the normal staining with core MUC2 antibody, was expressed diffusely in cells in some areas.

$\S$ Was expressed diffusely in cells in several areas, some co-localized with MUC2.
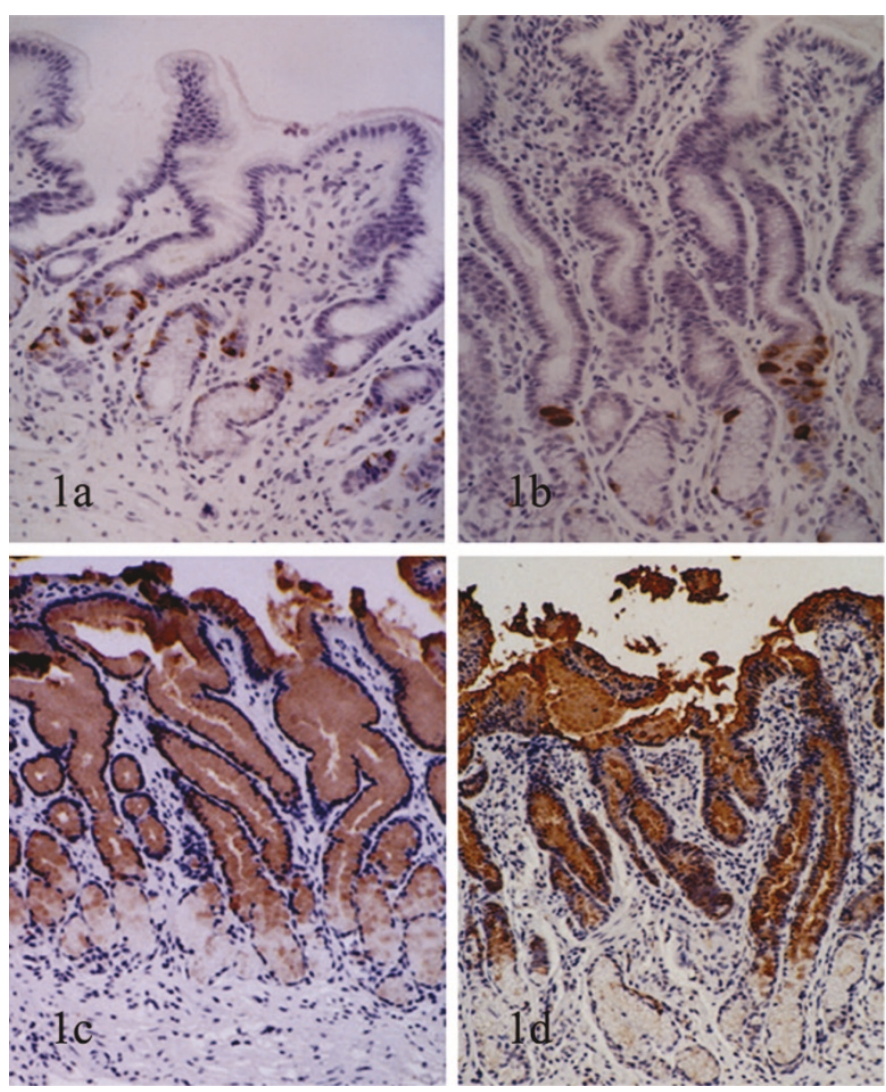

Figure 1. Antral biopsy showing the distribution of CMG, an early marker of neuroendocrine cells, showing stained cells in the basal one third of the antral glands in both normal control $(a)$ and our patient $(b)$. MUC5AC-containing cells occupied similar superficial areas of antral glands in biopsy sections from normal control $(c)$ and our patient $(d)$.

Large intestine. The colon showed pancolitis with relative sparing of the rectum. Initial surveys of H\&E-stained sections from colonic biopsies showed severe inflammation and a universal absence of goblet cells. Surprisingly, however, PCR from rectal biopsies revealed MUC2 mRNA, indicating that the colon, unlike the duodenum, expressed mucin mRNA (Fig. $3)$. As shown in a representative section typical of most of the colonic mucosa (Fig. 4), most of the tissue consisted of inflam- matory cells with a few glands and a flattened cuboidal surface epithelium. Some of the surface and glandular cells contained PAS/Alcian Blue-positive cells (Fig. 4a). These cells expressed both MUC2 (Fig. 4b) and MUC5AC (Fig. 4c) antigens, suggesting that they represented mucus epithelial cells that had lost their goblet cell phenotype. Co-expression of gastric and intestinal antigens is a feature of gastric metaplasia (16). Although not seen in the mucosa distal to the cecum, patches of gastric metaplasia were present in cecal biopsies (data not shown).

None of the biopsies from any area ever had granulomata. Immunostaining for cytomegalovirus was negative. The lymphocytic infiltrate was predominately composed of $\mathrm{T}$ cells. PCR indicated a clonal T cell population. Southern blot analysis was negative for rearrangement of the T cell receptor gene, in keeping with an inflammatory process rather than lymphoma.

Follow-up. Repeated endoscopic evaluation of the upper and lower gastrointestinal tract continued to show a pancolitis without goblet cells and further development of gastric metaplasia in the colon. The duodenal histology remained unchanged. No granulomata were ever seen. After a third trial of high-dose i.v. steroids, a few mature-looking goblet cells appeared in some colonic biopsies. Although upper intestinal inflammation improved, there was still no evidence of any type of secretory cells in the small intestine. Unfortunately, there was not significant clinical improvement, and the patient remains on parenteral nutrition.

\section{METHODS}

Approval to obtain biopsies or use archival tissue as control biopsies was received from the Research Ethics Committee of the Hospital for Sick Children. An informed consent was obtained from the patient and his legal guardians. Control biopsy sections were from age and sex-matched normal individuals (NC) or patients with either ulcerative colitis (UC) or Crohn's disease $(\mathrm{CD})$. A single senior pathologist with expertise in gastrointestinal pathology (E.C.) reviewed all slides.

Immunohistochemical methods. Biopsies were fixed in 3.7\% formalin, embedded in paraffin, and stained with H\&E and PAS/Alcian blue. Other specimens were prepared by antigen retrieval technique for the immunostaining (17). Immunostaining was done to detect CMG (Sera Lab, Leicestershire, England), serotonin (Sera Lab), gastrin (Dako, Fort Collins, CO), MUC2 core (Novocastra Labs., New-Castle, England), glycosylated MUC2 [an antibody 

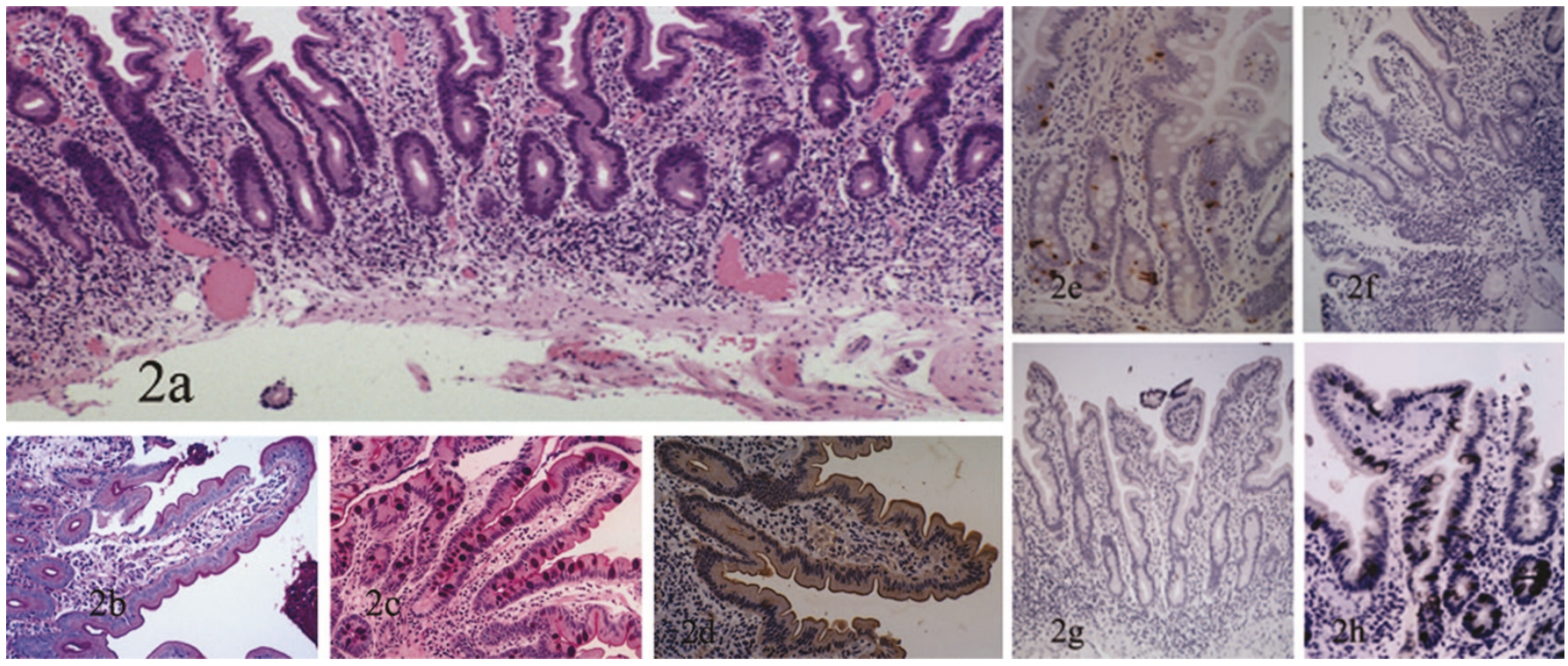

Figure 2. Sections from the patient's duodenum stained with H\&E (a) show a moderate increase in inflammatory cells within the lamina propria and some villus blunting with a slightly increased crypt:villus ratio. Absence of goblet cells in both villi and crypts is noted. This feature is even more striking in sections that were stained by PAS/Alcian Blue, which reveal an intact brush border without goblet cells $(b)$ and is contrasted with sections that were similarly stained from a control biopsy that show multiple Alcian Blue-positive goblet cells in a similar area $(c)$. $(d)$ Normal sucrase staining of patient's brush border. $(e)$ A biopsy specimen from a control biopsy showing the localization of CMG within typical enteroendocrine cells in both crypts and villi, whereas a similar area from patient shows no staining $(f)$. Similarly, $g$ shows no staining for the MUC2 core antigen throughout the mucosa from the case, whereas a control biopsy $(h)$ reveals the normal distribution of this antibody within the ER/Golgi zone of goblet cells.

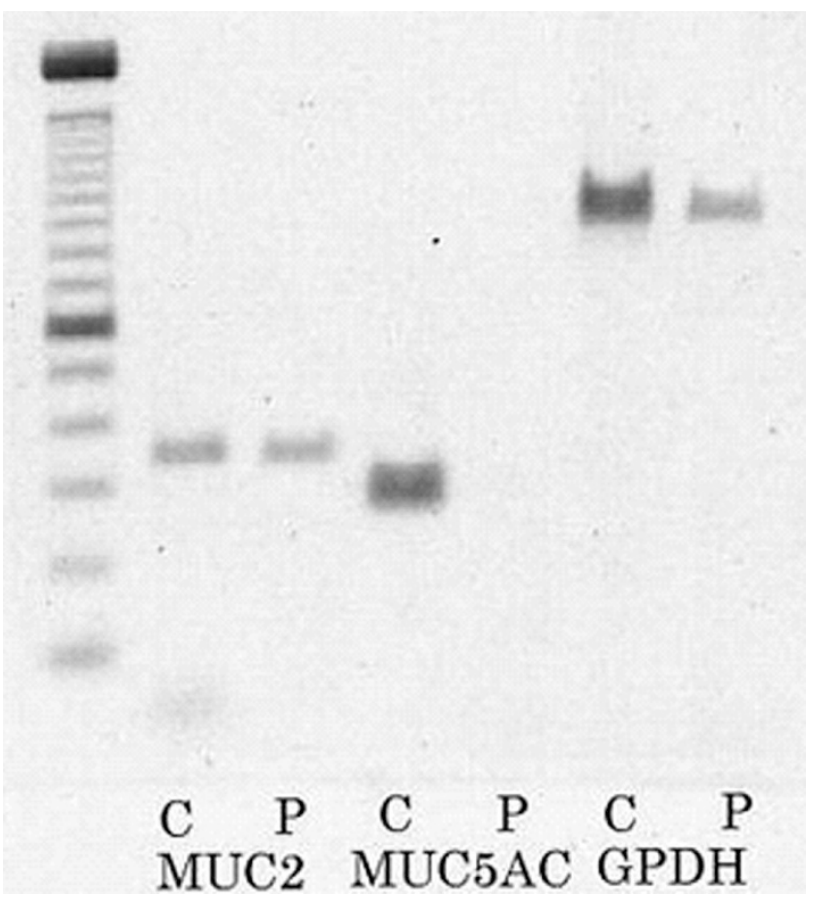

Figure 3. RT-PCR of a rectal biopsy from the patient (P) showing MUC2 expression and no MUC5AC expression. The control sections (C) were from the HT29A1 cell line, which expresses both MUC2 and MUC5AC.

developed in our lab (18)], MUC5AC (19), TFF1 (Biomeda, Foster City, CA), TFF3 (ITF) (20) (given by Dr. D. Podolsky, Massachusetts General Hospital, Boston, MA), rat sucrase (21) (given by Dr. A. Moore, HSC, Toronto), HD5 (22) (given by Dr. T. Ganz, UCLA, Los Angeles, CA), and MIB1 (15) (Beckman Coulter, Fullerton, CA).

Reverse transcription-PCR. RNA was extracted from six rectal biopsies from the patient. The HT29A1 cell line served as control. One microgram of total RNA was reverse-transcribed with $50 \mathrm{U}$ of Moloney murine leukemia virus reverse transcriptase (Perkin Elmer, Foster City, CA), $2.5 \mu \mathrm{M}$ random hexamer, $1 \mathrm{mM}$ dGTP, $1 \mathrm{mM}$ dATP, $1 \mathrm{mM}$ dTTP, $1 \mathrm{mM}$ dCTP, and 20 units of RNase inhibitor in a total volume of $20 \mu \mathrm{L}$ for $30 \mathrm{~min}$ at $42^{\circ} \mathrm{C}$. PCR was performed in a $50-\mu \mathrm{L}$ reaction that contained 0.5 unit of Taq polymerase (Perkin Elmer), $125 \mu \mathrm{M}$ each dNTP, $2 \mathrm{mM} \mathrm{MgCl}_{2}, 50 \mathrm{mM} \mathrm{KCl}, 10 \mathrm{mM}$ Tris- $\mathrm{HCl}(\mathrm{pH} 8.3$ ), and $0.1 \mathrm{mM}$ primers. Primers for MUC2, MUC5AC, and GPDH were synthesized according to published sequences (23-25). PCR was carried out according to Hong et al. (26).

\section{DISCUSSION}

The lack of any normal-appearing granule that contained epithelial cells in the small intestine of this case suggests a failure of normal epithelial lineage differentiation. The gut epithelium is normally composed of four different cell types, which are thought to be derived from a single multipotential stem cell that lies in the crypts of Lieberkühn (1-4). This multipotential stem cell divides into a daughter cell that then, through an ill-defined process, finally becomes one of four cell types, a Paneth cell, a goblet cell, a neuroendocrine cell, or an enterocyte. Three of the lines (goblet, Paneth, and neuroendocrine) eventually develop secretory granules.

The finding in this case raises several questions. The lack of any mature-appearing granule containing epithelial cell suggests that there could be a second branching point where the daughter cell further divides into an enterocyte or a granulecontaining epithelial cell. The fact that there is evidence of mucin-containing cells in the colon, but not in the small intestine further supports the evidence that regulatory factors for epithelial cell differentiation may not be the same for all of the length of the gastrointestinal tract.

Differentiation studies have been undertaken using colonic adenocarcinoma cell lines. In particular, the HT29 cell line has been of interest because it is the only cell line of intestinal 


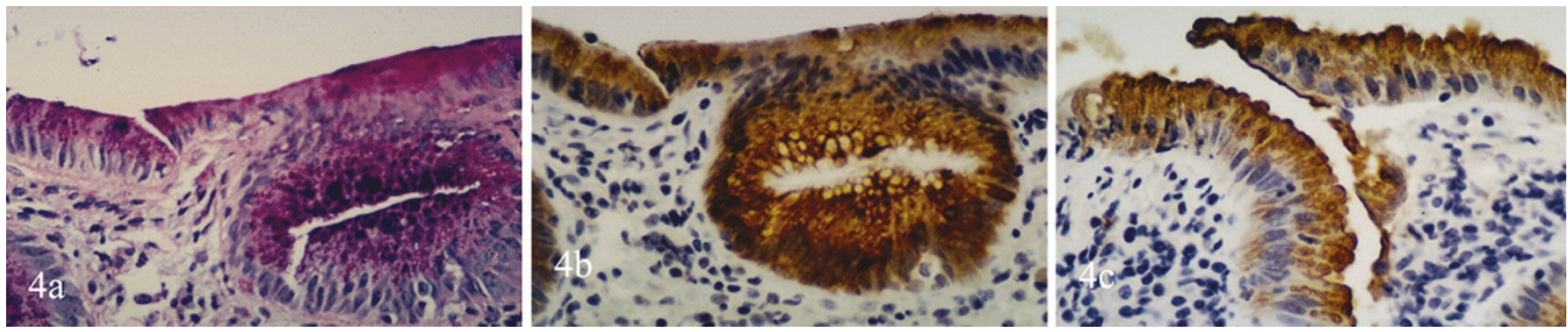

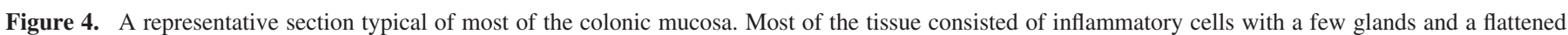

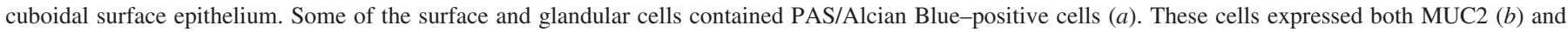
MUC5AC (c) antigens.

origin to reversibly display structural and functional features of mature intestinal epithelial cells (27). In culture, these cells are heterogeneous with a small proportion of mucous cells and columnar absorptive cells (28). Subclones of the HT29 exhibit characteristic absorptive and goblet cells $(27,29)$. Agents such as sodium butyrate $(30,31)$, retinoic acid $(32,33), 1,25$ dihydroxyvitamin $\mathrm{D}_{3}$ (34), suramin $(35,36)$, spermine (37), and methotrexate (38) can induce changes suggestive of a more differentiated phenotype. Thus, exposure of these cells, which have a potential to develop along one or another lineage, to agents that might be found in the fecal stream may promote differentiation.

Intestinal growth, differentiation, and adaptation are likely affected by various host cell factors, including cell-cell interactions $(13,39)$; extracellular matrix and mesenchymal cells $(13,21)$; hormones and peptides (40-42); luminal factors, such as diet $(39,41)$; and factors that are produced by endogenous bacteria, such as butyrate (43), and secreted products from salivary glands, gall bladder, and pancreas $(42,44)$ also play a part in regulating differentiation. Other important participants include PDGF A and its receptor, PDGF-Ra; the winged helix transcription factor Fkh6; the homeodomain transcription factor Nkx2-3; and Hox and ParaHox cluster genes, Sonic hedgehog, and bone morphogenetic proteins. Intraepithelial lymphocytes and microbes may be additional modulators (13). A recent study of Hesl knockout mice indicated that, as in other systems, notch signaling is an important contributor to lineage specification (7). Taking together all of the recent advances in the field of small bowel differentiation, the bottom line is that no one really knows what the exact interplay between these factors and stem cell differentiation is $(13,45)$. Thus, any single factor or combination of these factors could have influenced the further differentiation to a mature goblet cell in the colon.

Paneth cells were originally thought to play a major role in the regulation of proliferation and differentiation of the small bowel, but a study by Garabedian et al. (4) showed that ablation of the Paneth cell lineage did not affect the development of the other three lineages. In the same paper, ablation of the Paneth cells resulted in an intermediate cell somewhere between a Paneth cell and a granule-containing goblet cell, which subsequently became a mature goblet cell. So the lack of mature Paneth cells alone cannot explain the failure of stem cell development into goblet and neuroendocrine cells. The presence of an intermediate cell type also suggests that there may be a second major branching point, where the first daughter cell may be able to become either a Paneth or a goblet cell, depending on the right circumstances.

In their important paper, Bjerknes and Cheng (46) found that the crypt contains both short-lived (days) and long-lived (months) unipotential columnar cell progenitors or mucous cell progenitors and bipotential progenitors of the enterocytic and goblet cell lineages, as well as long-lived multipotent stem cells that are capable of giving rise to all epithelial cell types. We could not find in our patient any evidence to these mix progenitors.

Katz et al. (9) showed that Klf4 (formerly GKLF), a zincfinger transcription factor, is a goblet cell-specific differentiation factor in the colon. This suggests a distinction between differentiation of colon versus small intestinal goblet cells and might explain the discrepancy of MUC2 production in the colon and not in the small bowel.

A recent study by Yang et al. (6) found that loss of Mathl, a basic helix-loop-helix transcription factor that is expressed in the gut, leads to depletion of goblet, enteroendocrine, and Paneth cells without affecting enterocytes. Colocalization of Mathl with Ki-67 in some proliferating cells suggests that secretory cells (goblet, enteroendocrine, and Paneth cells) arise from a common progenitor that expresses Mathl, whereas absorptive cells (enterocytes) arise from a progenitor that is Mathl independent. These findings support our theory of a common progenitor for the secretory granules cell lineage progenitor.

Protein products of the various cell lineages are often expressed early during embryonal development (47). Detection of these proteins using various markers has been used to try to follow cells through the differentiation process. These markers may be present long before the mature phenotype is evident and possibly suggest the future potential of the cell.

MUC2, the major intestinal mucin, appears as early as $12 \mathrm{wk}$ gestation and is expressed in individual cells throughout the intestinal epithelium (48). In the case study, there was evidence of mRNA for MUC2 from the rectal biopsies. This was not the case for his small intestine. Thus, one suspects that he had at least the genetic ability to produce MUC2 and then goblet cells in the large intestine. This actually happened later in his course. The lack of any evidence, even at the level of mRNA, for MUC2 in the small intestine supports the theory that the insult was at a very basic level. Thus, it seems that the ability for differentiation and end product formation, even along one line, varies from one area to another. 
Darmoul et al. (49) found cryptdin gene expression in the immature intestinal epithelium of newborn mice despite an absence of differentiated crypts or recognizable Paneth cells. Cryptdin is the mouse analogue of HD, a Paneth cell product. HD5 and HD6 are present at 13.5 wk gestation in human fetuses and localize to crypts (50). In our study, normal control small intestine was positive, as one would expect, for HD5. In the disease controls, there was overexpression of this marker, possibly in response to inflammation. The case study small intestine had no positive staining, even when severely inflamed.

CMG and TFF3 are also used as markers of early differentiation. CMG is currently the most sensitive marker for endocrine differentiation in normal and neoplastic tissue (51). TFF3 is a member of the trefoil factor family and eventually locates to Brunner's gland acini and goblet cells in both the large and small intestines (52). The trefoil proteins are secreted by mucin-secreting epithelial cells and are believed to be important for mucosal protection and repair. Normal controls, as expected, had positive staining for both of these markers. Inflamed control duodenum again had overexpression of these markers. The case study was negative, which correlated with the lack of neuroendocrine, Paneth, or goblet cells. In fact, given the results in the disease controls, one might actually expect overexpression of these markers in the case study in response to the inflammation in the intestinal biopsies.

Several patients with Crohn's disease with inflamed duodenum served as control to ensure that the case findings were not simply a local response to inflammation. All of the markers studied (MUC2, HD5, CMG, TFF1, and TFF3) were present in both healthy and disease control subjects. In fact, we found overexpression of TFF3 and TFF1 in Crohn's disease (Prof. D. Podolsky, Gastrointestinal Unit, Department of Medicine, Center for the Study of Inflammatory Bowel Disease, Massachusetts General Hospital and Harvard Medical School, Boston, MA 02114, personal communication June 1997), suggesting that the changes in our patient's duodenum did not simply reflect response to inflammation.

Although the patient's colon did not express goblet cells early on, there was MUC2 and TFF3 expression in colonocytes. This is in contrast to the small bowel findings. The distribution of core MUC2 in the colon epithelial cells suggests an incomplete mucin processing. Colonic biopsies from patients with inflammatory bowel disease (IBD) exhibit similar findings in areas of goblet cell depletion (53).

Although Paneth cells are usually not present in the colon, there is often Paneth metaplasia in patients with colitis $(54,55)$. HD5, a marker for Paneth cells, was not present in our patient's colonic biopsies. Given the degree of inflammation, including the presence of gastric metaplasia, one would have expected to observe Paneth cell metaplasia in this case. As well, trefoil factors have been shown to be overexpressed in both the large and small bowel in Crohn's disease (52). Their presence is believed to be important for repair of the intestinal mucosa. Gastric metaplasia is seen frequently in the inflamed colon of patients with IBD (56). TFF1 has been shown to be expressed in IBD in areas of ulcers and in areas of gastric metaplasia (57). The expression of MUC5AC and TFF1 in some areas of the colon in this patient may be a part of gastric metaplasia secondary to the inflammatory process and may reflect an ability to start differentiation in the colon, unlike the small bowel. Both intestinal mucus and trefoil factors are believed to have a mucosal protective effect in the intestine (58). We postulate that a lack of luminal factors that would have been produced by the absent mature small intestinal epithelial cells may play a decisive role in the health and response to inflammation in the colon.

Although inflamed, antral epithelial differentiation seemed normal on the basis of morphology and expression of the markers. The stomach, unlike the colon, may not be dependent on factors from the small bowel for normal differentiation, or, simply, the modulators for epithelial cell differentiation may be different in the stomach.

Positive anti-goblet cell antibodies were present in serum in both our patient (in low titer) and a patient described by Moore et al. (14). They described a similar case of childhood-onset diarrhea and absence of colonic and intestinal goblet cells. On the basis of the presence of the anti-goblet cell antibodies, increased class II antigen expression by epithelial cells, and IgA deficiency as well as some response to immunosuppressive therapy, the authors postulated an autoimmune cause. We reviewed the biopsies from this case and discovered that there were also no Paneth or neuroendocrine cells present. Some goblet and enteroendocrine cells were observed in small bowel biopsy after immunosuppressive treatment. This has never happened in our patient. Since the publication of this case, anti-goblet cell antibodies have been described in many patients with IBD $(59,60)$, and a positive anti-goblet cell antibody may simply be secondary to the inflammation.

\section{CONCLUSION}

In conclusion, our current knowledge suggests a common precursor for all intestinal cell lines. This differentiation process is highly complex and controlled by multiple factors. We speculate that our findings, mainly in the small bowel, are the result of an early block in lineage development at a step common to all three granule-producing cell lines. This "human model" confirms the mouse small bowel differentiation model presented by Bjerknes and Cheng (46). We believe that this mistake of nature can add to our understanding of the normal small bowel differentiation.

\section{REFERENCES}

1. Bjerknes M, Cheng H 1981 The stem-cell zone of the small intestinal epithelium. III. Evidence from columnar, enteroendocrine, and mucous cells in the adult mouse. Am J Anat 160:77-91

2. Cheng H, Leblond CP 1974 Origin, differentiation and renewal of the four main epithelial cell types in the mouse small intestine. V. Unitarian Theory of the origin of the four epithelial cell types. Am J Anat 141:537-561

3. Falk P, Lorenz RG, Sharon N, Gordon JI 1995 Moluccella laevis lectin, a marker for cellular differentiation programs in mouse gut epithelium. Am J Physiol 268:G553G567

4. Garabedian EM, Roberts LJ, McNevin MS, Gordon JI 1997 Examining the role of Paneth cells in the small intestine by lineage ablation in transgenic mice. J Biol Chem 272:23729-23740

5. Ouko L, Ziegler TR, Gu LH, Eisenberg LM, Yang VW 2004 Wnt11 signaling promotes proliferation, transformation, and migration of IEC6 intestinal epithelial cells. J Biol Chem 279:26707-26715

6. Yang Q, Bermingham NA, Finegold MJ, Zoghbi HY 2001 Requirement of Math1 for secretory cell lineage commitment in the mouse intestine. Science 294:2155-2158 
7. Jensen J, Pedersen EE, Galante P, Hald J, Heller RS, Ishibashi M, Kageyama R, Guillemot F, Serup P, Madsen OD 2000 Control of endodermal endocrine development by Hes-1. Nat Genet 24:36-44

8. Beck F 2002 Homeobox genes in gut development. Gut 51:450-454

9. Katz JP, Perreault N, Goldstein BG, Lee CS, Labosky PA, Yang VW, Kaestner KH 2002 The zinc-finger transcription factor Klf4 is required for terminal differentiation of goblet cells in the colon. Development 129:2619-2628

10. Ohnishi S, Laub F, Matsumoto N, Asaka M, Ramirez F, Yoshida T, Terada M 2000 Developmental expression of the mouse gene coding for the Kruppel-like transcription factor KLF5. Dev Dyn 217:421-429

11. Bieker JJ 2001 Kruppel-like factors: three fingers in many pies. J Biol Chem 276:34355-34358

12. Ng AY, Waring P, Ristevski S, Wang C, Wilson T, Pritchard M, Hertzog P, Kola I 2002 Inactivation of the transcription factor Elf3 in mice results in dysmorphogenesis and altered differentiation of intestinal epithelium. Gastroenterology 122:1455-1466

13. Mills JC, Gordon JI 2001 The intestinal stem cell niche: there grows the neighborhood. Proc Natl Acad Sci USA 98:12334-12336

14. Moore L, Xu X, Davidson G, Moore D, Carli M, Ferrante A 1995 Autoimmune enteropathy with anti-goblet cell antibodies. Hum Pathol 26:1162-1168

15. Cattoretti G, Becker MH, Key G, Duchrow M, Schluter C, Galle J, Gerdes J 1992 Monoclonal antibodies against recombinant parts of the Ki-67 antigen (MIB 1 and MIB 3) detect proliferating cells in microwave-processed formalin-fixed paraffin sections. J Pathol 168:357-363

16. Shaoul R, Marcon P, Okada Y, Cutz E, Forstner G 2000 The pathogenesis of duodenal gastric metaplasia: the role of local goblet cell transformation. Gut 46:632638

17. Lahoti C, Thorner P, Malkin D, Yeger H 1996 Immunohistochemical detection of p53 in Wilms' tumors correlates with unfavorable outcome. Am J Pathol 148:1577-1589

18. McCool DJ, Forstner JF, Forstner GG 1994 Synthesis and secretion of mucin by the human colonic tumour cell line LS180. Biochem J 302:111-118

19. Sotozono M, Okada Y, Sasagawa T, Nakatou T, Yoshida A, Yokoi T, Kubota M, Tsuji T 1996 Novel monoclonal antibody, SO-MU1, against human gastric MUC5AC apomucin. J Immunol Methods 192:87-96

20. Podolsky DK, Lynch-Devaney K, Stow JL, Oates P, Murgue B, De-Beaumont M, Sands BE, Mahida YR 1993 Identification of human intestinal trefoil factor. Goblet cell-specific expression of a peptide targeted for apical secretion. J Biol Chem 268:12230

21. Ferretti E, Li S, Wang J, Post M, Moore A 1996 Mesenchymal regulation of differentiation of intestinal epithelial cells. J Pediatr Gastroenterol Nutr 23:65-73

22. Porter EM, Liu L, Oren A, Anton PA, Ganz T 1997 Localization of human intestinal defensin 5 in Paneth cell granules. Infect Immun 65:2389-2395

23. Guyonnet Duperat V, Audie JP, Debailleul V, Laine A, Buisine MP, GaliegueZouitina S, Pigny P, Degand P, Aubert JP, Porchet N 1995 Characterization of the human mucin gene MUC5AC: a consensus cysteine-rich domain for 11p15 mucin genes? Biochem J 305:211-219

24. Toribara NW, Gum JR, Culhane PJ, Lagace RE, Hicks JW, Petersen GM, Kim YS 1991 MUC-2 human small intestinal mucin gene structure. Repeated arrays and polymorphism. J Clin Invest 88:1005-1013

25. Tso JY, Sun XH, Kao TH, Reece KS, Wu R 1985 Isolation and characterization of rat and human glyceraldehyde-3-phosphate dehydrogenase cDNAs: genomic complexity and molecular evolution of the gene. Nucleic Acids Res 13:2485-2502

26. Hong DH, Forstner JF, Forstner GG 1997 Protein kinase C-epsilon is the likely mediator of mucin exocytosis in human colonic cell lines. Am J Physiol 272:G31G37

27. Schroy PC, Rustgi AK, Ikonomu E, Liu XP, Polito J, Andry C, O'Keane JC 1994 Growth and intestinal differentiation are independently regulated in HT29 colon cancer cells. J Cell Physiol 161:111-123

28. Dahiya R, Lesuffleur T, Kwak KS, Byrd JC, Barbat A, Zweibaum A, Kim YS 1992 Expression and characterization of mucins associated with the resistance to methotrexate of human colonic adenocarcinoma cell line HT29. Cancer Res 52:4655-4662

29. Huet C, Sahuquillo-Merino C, Coudrier E, Louvard D 1987 Absorptive and mucussecreting subclones isolated from a multipotent intestinal cell line (HT-29) provide new models for cell polarity and terminal differentiation. J Cell Biol 105:345-357

30. Kim YS, Tsao D, Siddiqui B, Whitehead JS, Arnstein P, Bennett J, Hicks J 1980 Effects of sodium butyrate and dimethylsulfoxide on biochemical properties of human colon cancer cells. Cancer 45:1185-1192

31. Augeron C, Laboisse CL 1984 Emergence of permanently differentiated cell clones in a human colonic cancer cell line in culture after treatment with sodium butyrate. Cancer Res 44:3961-3969

32. Tsao D, Morita A, Bella AJ Jr, Luu P, Kim YS 1982 Differential effects of sodium butyrate, dimethyl sulfoxide, and retinoic acid on membrane-associated antigen, enzymes, and glycoproteins of human rectal adenocarcinoma cells. Cancer Res 42:1052-1058

33. Niles RM, Wilhelm SA, Thomas P, Zamcheck N 1988 The effect of sodium butyrate and retinoic acid on growth and CEA production in a series of human colorectal tumor cell lines representing different states of differentiation. Cancer Invest 6:39-45
34. Tanaka Y, Bush KK, Eguchi T, Ikekawa N, Taguchi T, Kobayashi Y, Higgins PJ 1990 Effects of 1,25-dihydroxyvitamin D3 and its analogs on butyrate-induced differentiation of HT-29 human colonic carcinoma cells and on the reversal of the differentiated phenotype. Arch Biochem Biophys 276:415-423

35. Fantini J, Rognoni JB, Roccabianca M, Pommier G, Marvaldi J 1989 Suramin inhibits cell growth and glycolytic activity and triggers differentiation of human colic adenocarcinoma cell clone HT29-D4. J Biol Chem 264:10282-10286

36. Baghdiguian S, Verrier B, Marvaldi J, Fantini J 1992 Short-term suramin treatment followed by the removal of the drug induces terminal differentiation of HT29-D4 cells. J Cell Physiol 150:168-174

37. ter Steege JC, Buurman WA, Forget PP 1997 Spermine induces maturation of the immature intestinal immune system in neonatal mice. J Pediatr Gastroenterol Nutr 25:332-340

38. Lesuffleur T, Barbat A, Dussaulx E, Zweibaum A 1990 Growth adaptation to methotrexate of HT-29 human colon carcinoma cells is associated with their ability to differentiate into columnar absorptive and mucus-secreting cells. Cancer Res 50:6334-6343

39. Sanderson IR, Ezzell RM, Kedinger M, Erlanger M, Xu ZX, Pringault E, LeonRobine S, Louvard D, Walker WA 1996 Human fetal enterocytes in vitro: modulation of the phenotype by extracellular matrix. Proc Natl Acad Sci USA 93:7717-7722

40. Chu SH, Walker WA 1991 Growth factor signal transduction in human intestinal cells. Adv Exp Med Biol 310:107-112

41. Drucker DJ 1997 Epithelial cell growth and differentiation. I. Intestinal growth factors. Am J Physiol 273:G3-G6

42. Thomson AB, Jarocka-Cyrta E, Faria J, Wild GE 1997 Small bowel review-part I. Can J Gastroenterol 11:49-56

43. Gum JR, Kam WK, Byrd JC, Hicks JW, Sleisenger MH, Kim YS 1987 Effects of sodium butyrate on human colonic adenocarcinoma cells. Induction of placental-like alkaline phosphatase. J Biol Chem 262:1092-1097

44. Tivey DR, Shulman RJ 1991 Effect of pancreatic secretions upon ileal disaccharidase activities of neonatal miniature pigs. Experientia 47:452-454

45. Wong MH, Stappenbeck TS, Gordon JI 1999 Living and commuting in intestinal crypts. Gastroenterology 116:208-210

46. Bjerknes M, Cheng H 1999 Clonal analysis of mouse intestinal epithelial progenitors. Gastroenterology 116:7-14

47. Bry L, Falk P, Huttner K, Ouellette A, Midtvedt T, Gordon JI 1994 Paneth cell differentiation in the developing intestine of normal and transgenic mice. Proc Nat Acad Sci USA 91:10335-10339

48. Chambers JA, Hollingsworth MA, Trezise AE, Harris A 1994 Developmental ex pression of mucin genes MUC1 and MUC2. J Cell Sci 107:413-424

49. Darmoul D, Brown D, Selsted ME, Ouellette AJ 1997 Cryptdin gene expression in developing mouse small intestine. Am J Physiol 272:G197-G206

50. Mallow EB, Harris A, Salzman N, Russell JP, DeBerardinis RJ, Ruchelli E, Bevins CL 1996 Human enteric defensins. Gene structure and developmental expression. J Biol Chem 271:4038-4045

51. de Bruine AP, Dinjens WN, van der Linden EP, Pijls MM, Moerkerk PT, Bosman FT 1993 Extracellular matrix components induce endocrine differentiation in vitro in NCI-H716 cells. Am J Pathol 142:773-782

52. Wong WM, Poulsom R, Wright NA 1999 Trefoil peptides. Gut 44:890-895

53. Shaoul R, Okada Y, Cutz E, Marcon MA 2004 Colonic expression of MUC2, MUC5AC, and TFF1 in inflammatory bowel disease in children. J Pediatr Gastroenterol Nutr 38:488-493

54. Tanaka M, Riddell RH, Saito H, Soma Y, Hidaka H, Kudo H 1999 Morphologic criteria applicable to biopsy specimens for effective distinction of inflammatory bowel disease from other forms of colitis and of Crohn's disease from ulcerative colitis. Scand J Gastroenterol 34:55-67

55. Dundas SA, Dutton J, Skipworth P 1997 Reliability of rectal biopsy in distinguishing between chronic inflammatory bowel disease and acute self-limiting colitis. Histopathology 31:60-66

56. Yokoyama I, Kozuka S, Ito K, Kubota K, Yokoyama Y 1977 Gastric gland metaplasia in the small and large intestine. Gut 18:214-218

57. Wright NA, Poulsom R, Stamp G, Van Norden S, Sarraf C, Elia G, Ahnen D, Jeffery R, Longcroft J, Pike C 1992 Trefoil peptide gene expression in gastrointestinal epithelial cells in inflammatory bowel disease. Scand J Gastroenterol Suppl 193:76-82

58. Wright NA 1993 Trefoil peptides and the gut. Gut 34:577-579

59. Hibi T, Ohara M, Kobayashi K, Brown WR, Toda K, Takaishi H, Hosoda Y, Hayashi A, Iwao Y, Watanabe M 1994 Enzyme linked immunosorbent assay (ELISA) and immunoprecipitation studies on anti-goblet cell antibody using a mucin producing cell line in patients with inflammatory bowel disease. Gut 35:224-230

60. Folwaczny C, Noehl N, Tschop K, Endres SP, Heldwein W, Loeschke K, Fricke H 1997 Goblet cell autoantibodies in patients with inflammatory bowel disease and their first-degree relatives. Gastroenterology 113:101-106 